\title{
コーターの排水処理設備（サイクルヒットシステム）
}

日本製紙(俐岩国工場 森 大之, 藤本康之, 貴船博巳, 竹中寿康, 大岩 修, 稲田 治

\section{Operating Experience of Cycle Hit System}

\author{
Hiroyuki Mori, Yasuyuki Fujimoto, Hiromi Kifune, \\ Kotoyasu Takenaka, Shuu Ooiwa and Osamu Inada \\ Iwakuni Mill Nippon Paper Industries Co., Ltd
}

Our Cycle Hit System of Iwakuni Mill started up from Febrary 1993 and Coated paper product waste liquor (Color waste liquor) has been treated succesfully with it.

In this system, primary plus secondary sludges are directed to a slugde conditioning tank, where it is dosed with an inorganic coagulant and mixed to neutralize the surface charge of the sludge particles.

This conditioned sludge is then sent to a pelletizing/thickening tank, where an anionic and an amphoteric polymers are added to pelletize the sludge. Using the same tank, water can be removed with a special built-in device, resuluting in a sludge with an increased concentration of solids.

This report described the summary of operation.

\section{1.はじめに}

日本製紙株岩国工場に於ける㳊工紙の製造は昭和 37 年に, 今では廃棄処分された 1 号コーターがスター トした事で始まった。その後, 順次設備增強を行い, 現在ではオフマシンコーター 3 台, オンマシンコー ター2 台, キャストコーター2 台の設備で, 月間 25,000 30,000 tの盜工紙を生産している。

この治工工程から排出される排水 (以後, カラー排 水と略) はペーパーマシン排水と混合し，その中に含 まれる樴維を随伴する形でクラリファイヤーにて，硫 酸バンド凝集沈海処理をして来た。

しかし，染工紙生産量の增加とともに，処理すべき カラー排水量も增加し,特にここ数年は,オーパーロー ドから安定した処理の確保が困難となり, その解決が 急務となった。

そこで, カラー排水の単独処理をどうにかして出来 ないかと言う覾点から, 新規排水処理設備について検 討したところ，下水污泥処理では既に実績の有る造粒 浱縮装置を用いた栗田工業侏製サイクルヒットシステ ムの導入により，良好な処理が出来る事を見い出した。 この設備の概要と本年 2 月からスタートした処理状況 について報告する。

\section{2. 算入経䋨}

\section{1 基本的な考元方}

塗工設備を增強したことによる排水処理設備の能力 不足であるから, 従来の処理設備能力を增強すれば良 いという考え方も有ったが，下記に示す理由により， 新規排水処理設備を導入し，カラー排水単独処理を目 指す事にした。

(1)クラリファイヤにて，賎維を随伴する形で硫酸バ ンド凝集沈激処理する従来の処理法を更に增强し たとしても,カラー排水由来の SS, COD の除去率 に限界が有る。また凝集污泥の脱水性も悪く, 脱 水ケーキの固形分が低い。

(2)色々な排水が混しり合う前に, 可能な限り発生源 に近い所で処理すれば，装軍がコンパクトとなる ばかりでなく，場合によっては，排水成分の回収 再利用の可能が生しる。従って, カラー排水の単 独処理を行う事により,カラー成分の回収再利用 の可能性も生しる。

(3)将来のコーター増設に際しても，その增設に適応 した排水処理設備を考虑すれば良い。

\section{2 新規排水処理設偳の探案}

前述の様に, カラー排水の単独処理を前提に, 複数 
の排水処理メーカーと接触し種々探索した。排水サン プルをメーカーに送り，ラボスケールにてテストした 結果，造粒浱縮法を用いたサイクルヒットシステム処 理で, カラー排水の単独処理が出来そうだという感触 を得た。

\section{3 デモ車による速綂処理テスト}

そこで, 次のステップとして, サイクルヒットシス テム一式を搭载したデモ車を岩国工場に持ち込み，カ ラー排水単独の連続処理テストを 7〜10 日間の期間で 都合 2 回繰り返し, ラボスケールのテスト結果が実際 に再現出来るのかを確かめた。

その結果, 固形分浱度で薄い物は $1 \%$ 弱から, 濃い物 は 5 6\%程度迄のカラー排水を処理しても, 処理水の SS は 100 ppm 以下で清澄度が高く，また凝集物の脱 水性も非常に良好で固形分か 50〜 55\%となる事を確 かめ, 実機として採用出来る事を確認した。

次に,サイクルヒットについての概要を説明したい。

\section{3. サイクルヒットシステムの概要}

\section{1 サイクルヒットシステムとは}

下水道処理場から発生する污泥の脱水方法として開 発されたシステムで, 以下に示したフローに従い, 楽 品と装置の組み合わせにより, 污泥の調質から脱水ま でトータルで処理を行う。

(1)诶集助剤による污泥の荷垂中和と両性高分子凝集

鼡によるフロック化。

(2)フロックの數密化・造柆化 (ペレット化)。

(3)ペレット浱縮と分離水排水。

(4)浱縮ペレットの脱水。

\section{2 サイクルヒットの処理機楼}

1）凝集助剤による污泥の荷电中和と両性高分子 凝集郕によるフロック化

サイクルヒットシステムで重要なポイントの 1 つと なるのが, 先ず最初に行う污泥の調質, つまり, 污泥 を脱水し易い状態に改質・調整する工程で，荷電の中 和とフロック化を行う。一般的に污泥は負電荷を帯び, 水との親和性が高く多量の水分を含んでいる。そこで, アルミニュウム塩（硫酸バンドなど）の様な金属塩で 荷電の中和を充分に行い，水分含有量の少ない1次凝 集物を形成させ(图 1)，更にこの1次凝集物を両性高 分子凝集剤を用いて粗大フロック化する（図 2 )。

\section{2）フロックの政密化・造粒濰縮}

凝集助剤と両性高分子凝集剤の併用により，粗大フ ロックを形成させた後, 造粒化と浱縮を同時進行させ る造粒浱縮装置内で適当な峴找を与える・と，緻密で粒 径の大きな粒状フロック（ペレット）が生成する。

つまり，適当な擋汼を与える事により，槽内に既に

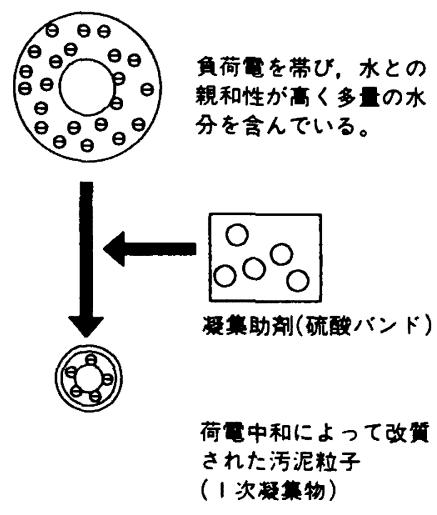

图 11 次凝集物の形成

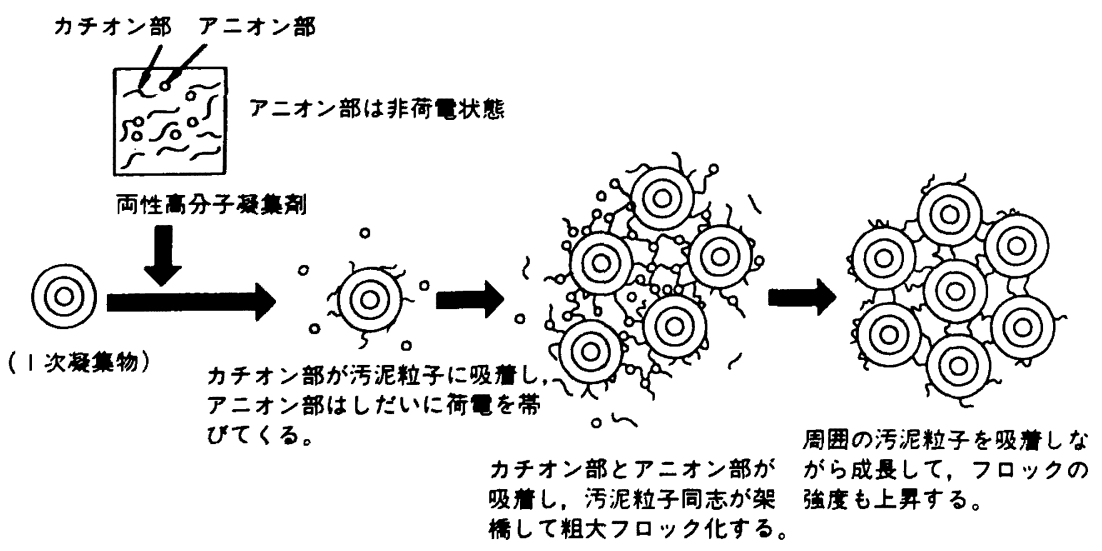

图 2 粗大フロックの形成 


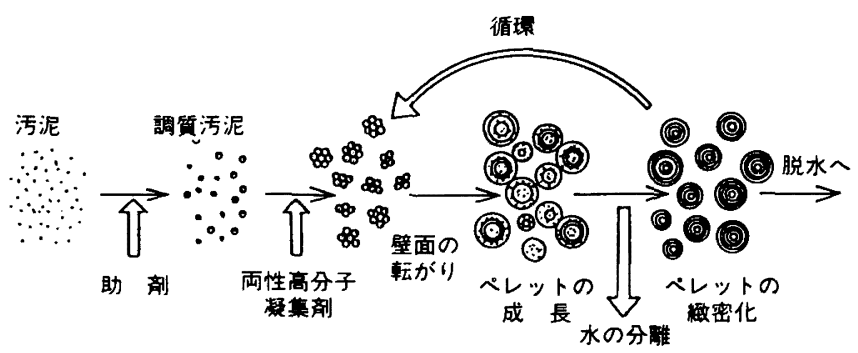

図 3 造粒調質式高効率直接脱水法の原理（モデル困）

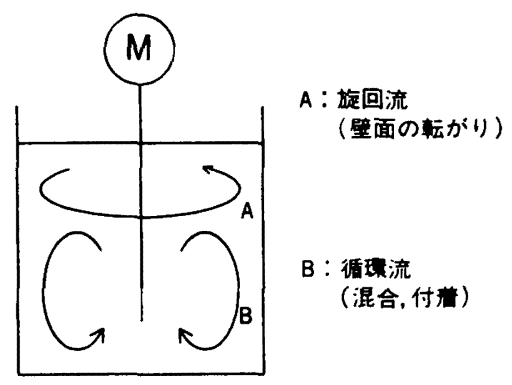

図 4 造粒に必要な槽内での流れ（モデル図）

存在する粗大フロックに新しく供給された粗大フロッ クと両性高分子准集郕が連続的に付着していき，槽の 壁面での転がり作用等によって，雪だるま式に緻密で 強度が強く，粒径の大きな $(10$ 20 mm) ペレットへ と成長し，上澄みとの分離性が良好となる(図 3 )。な お造粒装置内で混合, 付着作用と壁面の転がり作用を 与えて, 污泥を循環させるため, 槽内において, 循環 流と旋回流の 2 つの流れを拱拌で付与する（図 4 )。

3）ペレット渞縮と分崔水排出

前述の様に，造粒したペレットは粒径が大きく，強 度も強いため, ペレットと上澄みを分離する機能を組 み込めば，同一槽内で造粒と浱縮を同時に行う事が可
能となる。つまり, 污泥の供給と分離する水量の調節 を実施すれば, ペレットを任意の濃度に濃縮出来る。

造粒浱縮装置には，上部に槽内の旋回流と同一方向 になる様に，槽と同心円の円弧状水抜きスリットを設 置して有り，ペレットはこのスリットに沿って転がり， 上澄みだけがリットを通して系外に排出される。

この様に造粒装置から直接水のみを分離・排出して, 凝集と濃縮を同時に行うと, 従来の濃縮設備, つまり クラリファイヤーを必要とせず，非常にコンパクトな 設備となる。なお以上の一連のフロー概念モデルを図 5 に示した。

\section{4）㴧縮ペレットの脱水}

造粒浱縮装置で生成したペレットは，適正な濃度で 引き拔かれて, ベルトプレス型脱水機の重力脱水部に 送られる。ここで, 濾布を介して自然脱水された後, 多数の脱水ロールで更に筊られて低含水率の脱水ケー キが得られる(図6)。

\section{4. 設備内容及び処理状況}

\section{1 設借処理能力}

設備の処理能力は下記の条件を満たすものとした。

(1)カラー排水濃度変動対応：0.5 5 (\%)

(2) " 流量変動対応: $\operatorname{Max} 40\left(\mathrm{~m}^{3} / \mathrm{H}\right)$

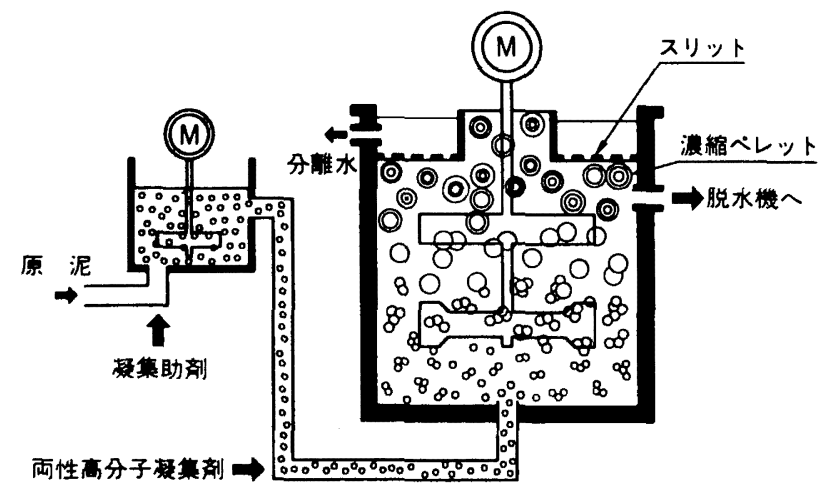

図 5 フロー概念モデル図 


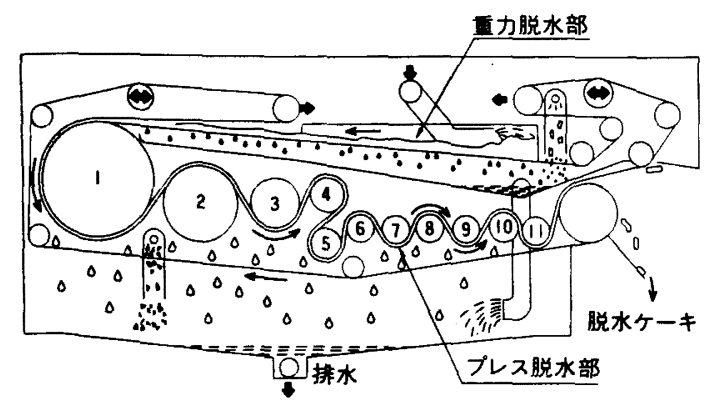

図 6 ベルトプレス型脱水機の概要
(3)処理 水 SS 濃度: 100 (ppm) 以下

(4) " COD 濃度: $500(\mathrm{ppm})$ 以下

(5)脱水ケーキ 処理量: Max $600(\mathrm{~kg} \mathrm{DS} / \mathrm{H})$

(6) $"$ 濃 度: $50(\%)$ 以上

$$
\text { * 55(\%) (目標) }
$$

\section{2 設備概要及び処理フロー}

設備の概要を表 1 に，処理フローを図7にそれぞれ 示した。今回導入した設備は, カラ一調薬室の隣接地 に設置し，運転管理をカラ一調薬室の操業員が行う方 式としたため, 可能な限り人手を掛けず, 全自動で連 続処理する事を大前提とした。

表 1 設備概要

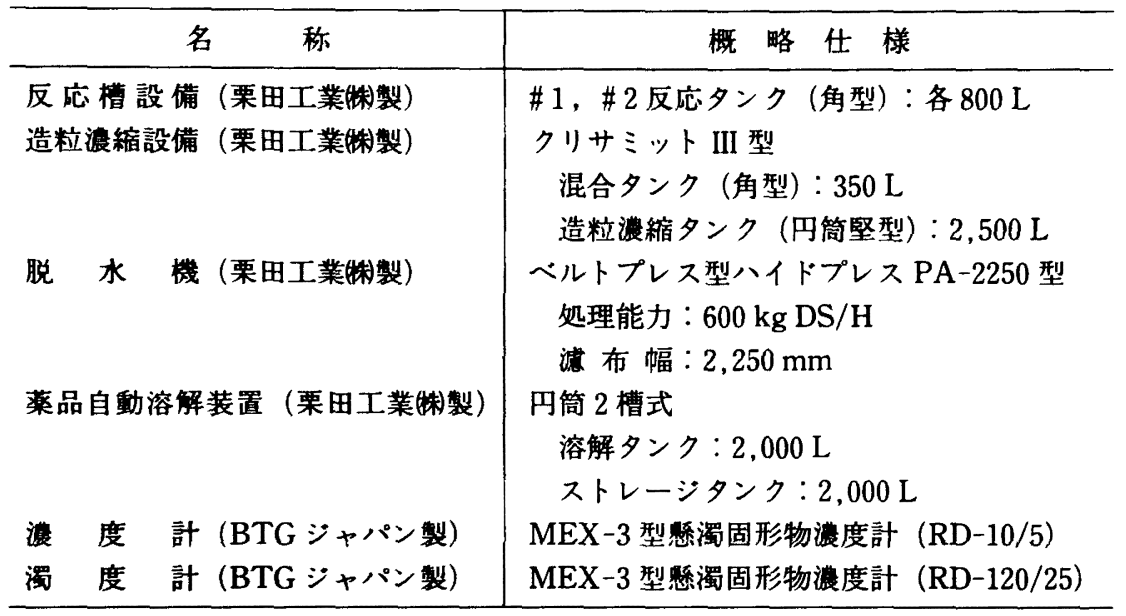

(a)

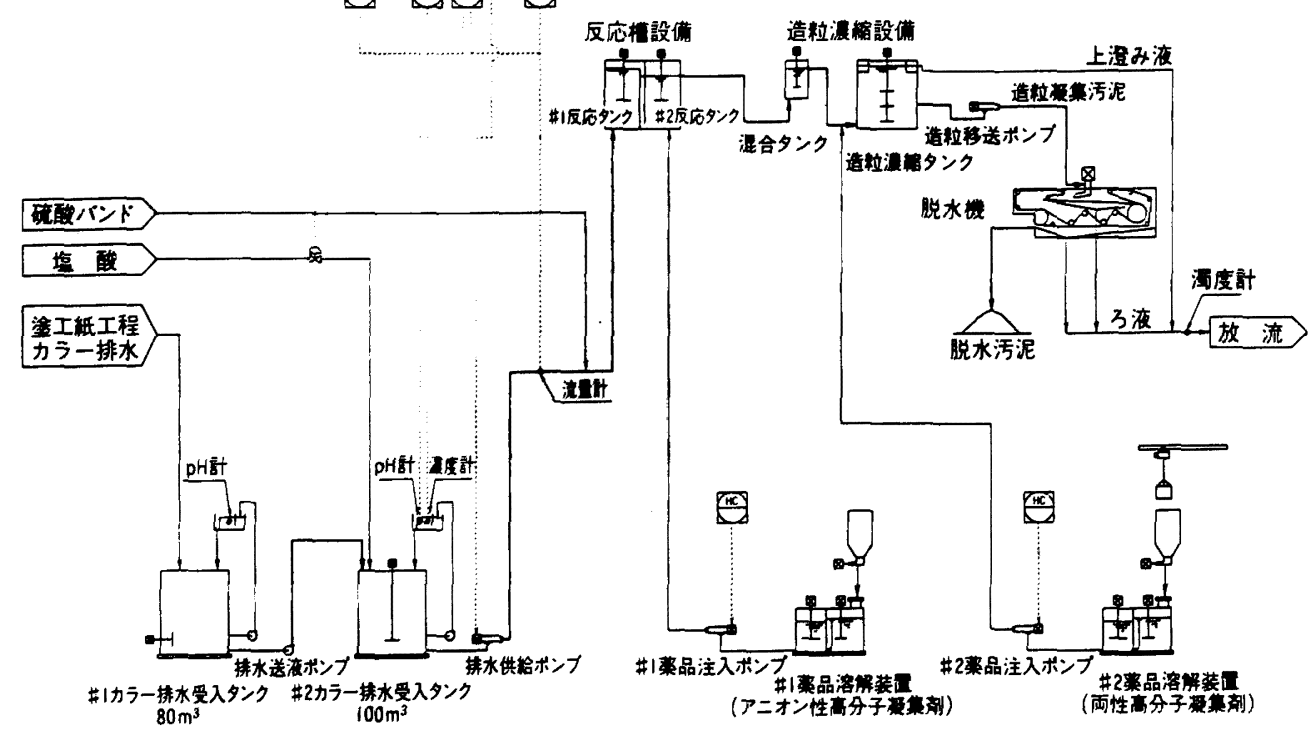

図 7 カラ一排水処理設備概略フローシート 
表 3 処理状況

\begin{tabular}{cc|cc|cc|c|cc}
\hline \multicolumn{2}{|c|}{ 原水 } & \multicolumn{2}{|c|}{ 処理水 } & \multicolumn{2}{c|}{ 除去率 } & \multicolumn{2}{c|}{ 脱水ケーキ } & \multicolumn{2}{c}{ 処理量 } \\
$\mathrm{SS}(\%)$ & $\mathrm{COD}(\mathrm{ppm})$ & $\mathrm{SS}(\mathrm{ppm})$ & $\mathrm{COD}(\mathrm{ppm})$ & $\mathrm{SS}(\%)$ & $\mathrm{COD}(\%)$ & 固形分 $(\%)$ & $\mathrm{m}^{3} / \mathrm{H}$ & $\mathrm{kgDS} / \mathrm{H}$ \\
\hline 5.0 & 4,938 & 100 & 490 & 99 & 90 & 56 & 12 & 600 \\
3.6 & 3,340 & 86 & 404 & 99 & 88 & 53 & 17 & 600 \\
2.0 & 1,870 & 64 & 312 & 99 & 83 & 57 & 30 & 600 \\
1.1 & 954 & 21 & 221 & 99 & 77 & 56 & 40 & 440 \\
0.7 & 716 & 37 & 165 & 99 & 77 & 55 & 40 & 280 \\
\hline
\end{tabular}

表 2 薬品添加率 （対固形分\%）

\begin{tabular}{c|c|c}
\hline 硫酸バンド*1 $^{* *}$ \#1 薬品*2 & $\# 2$ 薬品*3 \\
\hline $6.0 \sim 10.0$ & $0.20 \sim 0.30$ & $0.20 \sim 0.35$ \\
\hline
\end{tabular}

${ }^{* 1} \mathrm{Al}_{2}\left(\mathrm{SO}_{4}\right)_{3} \cdot 18 \mathrm{H}_{2} \mathrm{O}$ として

*2\# 1 薬品：アニオン性高分子凝集剤（クリフロッ ク PA-331)

*3\# 2 薬品：両性高分子凝集郕（クリベスト P704)

そこで, カラー調薬室の DCS で設備全体の運転か 自動で行える様に処理フローを設定し，自社ソフトで システム化した。特にカラー排水の濃度計については, 当初適当な機種が無かったため，いろいろ探索したと ころ, BTG ジャパン製の MEX-3 型懸濁固形物濃度 計を用いる事により手分析浱度と良好な相関性のある 検量線が得られ，保守管理も容易な事が判明したため これを設置した。

また処理水の監視用として, 同機種（検出浱度幅は 遠う）を設置した。

\section{3 処理状況}

本年 2 月よりスタートしたサイクルヒットシステム
によるカラー排水の処理では, 下水污泥処理で使用さ れる硫酸バンドと両性高分子凝集剤に加え，アニオン 性高分子凝集郕を硫酸バンドの後で適正量添加する事 (表 2 )により，カラー排水の濃度変動等にも十分追随 し, 現在, 処理水の面でも脱水ケーキの面でも, 良好 で安定した処理状況が䧴持出来ている(表 3)。

なお, 脱水ケーキのカラー成分としての回収再利用 については，ラボスケールによる試みを一部開始して いるが, 残念ながらまだ目処が立っていないため, 全 量をスラッジ焼却炉にて焼却処分している。

\section{まと め}

下水污泥の処理用に開発されたサイクルヒットシス テムを, 当岩国工場で初めてカラー排水処理用に導入 した。原則として殆ど人手を掛けず，全自動連続運転 が可能となる処理フローを設定し, 本年 2 月よりス タートした結果, 期待通りの処理効果が得られている ため, 今後もこれを維持していきたい。

最後に，今回の発表を行うにあたり，栗田工業俐の 花見勇一氏, 山口 忍氏, 向井治富氏, 川口信夫氏他 多くの方々の御協力を賜ったので, 感謝の意を表しま す。 